\title{
Job Satisfaction of Employees Undergoing Public Sector Reform in Fiji
}

\author{
Gurmeet Singh', Neale J. Slack ${ }^{2}$ \\ ${ }^{1}$ School of Management \& Public Administration, The University of The South Pacific, Suva, Fiji \\ ${ }^{2}$ Department of Uni Services, Fiji National University, Nasinu Campus, Suva, Fiji \\ Email: singh g@usp.ac.fj, njslack@gmail.com
}

Received 31 March 2016; accepted 25 April 2016; published 28 April 2016

Copyright (C) 2016 by authors and Scientific Research Publishing Inc.

This work is licensed under the Creative Commons Attribution International License (CC BY).

http://creativecommons.org/licenses/by/4.0/

(c) (i) Open Access

\begin{abstract}
This study analyses job satisfaction in the Maritime Safety Authority of Fiji (MSAF), a public sector entity undergoing reform. Results of this study determine that the level of MSAF employee job satisfaction by dimension was predominantly low; employees had a low level of intrinsic satisfaction, an average level of extrinsic satisfaction, and a low level of general satisfaction; and employees' level of job satisfaction was significantly lower than the reference group. This research makes its theoretical contribution primarily to the literature on public service job satisfaction, and to the scarce theoretical strands relating to public service safety organisations. A practical outcome of this research is its contribution towards ongoing public sector reforms in Fiji in general and MSAF and the maritime industry in particular.
\end{abstract}

\section{Keywords}

Job Satisfaction, Workforce Environment, Job Analysis, State Owned Enterprise (SOE)

\section{Introduction}

In spite of the significance of job satisfaction, research has concentrated on the private sector (Bajpai \& Srivastava, 2004) [1]. Far less public service job satisfaction research has been carried out (Ellickson, 2002; Pollock, et al., 2000; Kroll, 2011; Ibarra \& Andrews, 1993) [2]-[5], possibly due to the presumption that the job satisfaction determinants in both sectors were common (Ting, 1997) [6]. Whilst literature highlights the debate as to whether public and private sector workforce environments should be differentiated (Kroll, 2011) [4], several studies as stated by Wright (2001) [7] are in agreement that there is a difference (Baldwin \& Farley, 1991; Fottler, 1981; Rainey, 1989; Whorton \& Worthley, 1981) [8]-[11].

Public service employees generally are viewed as being more dissatisfied with their jobs than private sector counterparts (Baldwin \& Farley, 1991; Rainey 1989; Steel \&Warner, 1990) [8] [10] [12]. Supposed causes of 
this dissatisfaction have been that the structure of public service organisations hinder achievement of publicspirited needs of employees, ambiguous and conflicting goals makes understanding and achievement of goals difficult (Baldwin, 1984) [13], and poor compensation policies (Blank 1985; Fogel \& Lewin, 1974) [14] [15]. In contrast, empirical research that evaluated public service employee satisfaction has been far less consistent (Paine et al.,1966; Porter \& Mitchell, 1967; Rhinehart et al., 1969; Solomon, 1986) [16]-[19], whilst other studies have found contrary evidence (Newstrom et al., 1976) [20].

Considering the ongoing public sector reform in Fiji, and in particular relating to the Maritime Safety Authority of Fiji (MSAF), wide-ranging structural, operational, systemic and cultural change, focused on services being increasingly responsive to the needs and aspirations of their customers, necessitated a better understanding and enhancement of employee job satisfaction, bearing in mind the integral link between employee job satisfaction and customer service. Whilst this statement may appear obvious, it is evident from the reforms undertaken of the entities leading up to the establishment of MSAF, that the research necessary to provide such understanding was not carried out. Hence, this research of MSAF is unique in that it acknowledges that the starting point in developing employee job satisfaction is analysis and measurement (Edvardsen et al., 1994) [21].

In the following section we define and provide a theoretical background of job satisfaction, and describe approaches considered in assessing and evaluating job satisfaction. In Section 3 we define the main research problem, justification, and hypotheses of this study; and in the following sections we provide a description of the methodology adopted, results and discussion.

\section{Literature Review}

Satisfaction is considered to be important for motivating employees in the organisation (Velnampy \& Sivesan, 2012; Kumari et al., 2015) [22] [23]. The notion of job satisfaction has been extensively examined in literature, as a result of wide-ranging belief that it can impact on productivity and employee retention (Weiss et al., 1967) [24]. Whilst a plethora of definitions of job satisfaction exist, some are contradictory in nature (Miarkolaei \& Miarkolaei, 2014) [25]. Spector (1997) [26] defines job satisfaction as the degree by which employees like as opposed to dislike their jobs. Numerous researchers (Ellickson, 2002; Agho et al., 1993; Price \& Muller, 1986) [2] [27] [28] support the Spector (1997) [26] viewpoint and define job satisfaction as the extent to which employees like their work. Whilst other researchers view job satisfaction as a trove of attitudes, not only concerning the overall job, but concerning the different facets/dimensions of the job (Knoop, 2001; McCormick and Ilgen, 1985; Wanousand Lawler, 1972) [29]-[31].

Maslow's hierarchy of needs theory, and Herzberg's two-factor theory, being leading theories of job satisfaction, suggests job satisfaction consists of multiple dimensions (Herzberg et al., 1959; Maslow, 1954) [32] [33]. According to Herzberg motivation and Hygiene factors are important for increasing employee job satisfaction (Dartey-Baah \& Amoako, 2011) [34]. According to Prothero et al., (1999) [35], the majority of studies specify job satisfaction in terms of intrinsic and extrinsic rewards. Weiss et al. (1967) [24] categorize job satisfaction into three main types, namely: intrinsic, extrinsic, and total. According to Nachimuthu (2006) [36], intrinsic and extrinsic job satisfaction combines to form overall job satisfaction. Some researchers have categorized job satisfaction into two sources, namely, the work environment and the employee demographic characteristics (Michael \& Jihong, 1999) [37], and indicate employee demographic characteristics are a strong predictor of employee jobsatisfaction (Brunettoand Far-Wharton, 2002; Ellickson, 2002) [2] [38]. Job satisfaction of employees depends on relative pay comparisons as well (Card et al., 2012; Luthmer, 2005;Wenshu \& Smyth, 2010; Clark et al., 2009; Weathmgton et al., 2011) [39]-[43]. But results of a study recently done by Judge et al., (2010) [44] suggest that pay level is only marginally related to satisfaction.

Martins and Proenca (2012) [45] note that several approaches have been considered in assessing and evaluating job satisfaction in both theoretical and practical research. However, according to Spagnoli et al., (2012) [46] one of the greatest difficulties in assessing and evaluating job satisfaction is that it is possible to be satisfied with some aspects of a job and at the same time be dissatisfied with others. Literature recommends two principal approaches to measuring job satisfaction-an overall measure of job satisfaction, or one concerning several aspects of job satisfaction (Martins and Proenca, 2012) [45]. The first approach adopts a macro perspective and consists of questioning the respondent directly about their overall feelings about the job (Wanous et al., 1997) [47]; and the second approach accentuates different aspects of the job. It is the extent to which an individual is satisfied with several facets/dimensions of the job that dictates the overall degree of job satisfaction (Martins and Proenca, 2012) [45]. Some of the most popular measures in the field, for example, the Job Descriptive Index (Smith et al., 
1969) [48], the Minnesota Satisfaction Questionnaire (Weiss et al., 1967) [24], and the Job Satisfaction Survey (Spector, 1985) [49] adopt this perspective (Martins and Proenca, 2012) [45].

\section{Research Problem, Justification, and Hypotheses of the Study}

The main research problem is that since 1998 several efforts at public service reform of the precursor State Owned Enterprises (SOE's)leading up to, and of MSAF, have failed to appreciate the essential nature of employee satisfaction to the success of the business (Gregory \& Levy, 2011) [50], and consequently have failed to ensure high job satisfaction among employees. Research necessary to provide an understanding of MSAF employee job satisfaction as not previously carried out. This sets the stimulus for this research to examine the three measures of job satisfaction (intrinsic, extrinsic, general satisfaction); satisfaction levels of 20 specific job dimensions; the difference between MSAF employee general satisfaction and a reference group; and the correlation between MSAF employees' intrinsic, extrinsic and general job satisfaction. This research acknowledges that the starting point in developing employee job satisfaction is job analysis/evaluation and measurement. Four hypotheses are tested and form the basis from which to proceed with this research.

Hypothesis 1: There is no significant difference between the general satisfaction mean score of MSAF employees, and the general satisfaction mean of the reference group (engineers), in the employee population.

H0: $\mathrm{p}=77.88$ [the population mean is equal to 77.88 ]

H1: $\mathrm{p} \neq 77.88$ [the population mean is not equal to 77.88 ]

Hypothesis 2: There is no significant correlation between MSAF Employee's Intrinsic and Extrinsic Job Satisfaction.

H0: $\mathrm{p}=0$ [The correlation between the MSAF Employee's Intrinsic and Extrinsic Job Satisfaction is equal to zero, in the employee population.]

H2: $p \neq 0$ [The correlation between the MSAF Employee's Intrinsic and Extrinsic Job Satisfaction is not equal to zero, in the employee population.]

Hypothesis 3: There is no significant correlation between MSAF Employee's Intrinsic and General Job Satisfaction.

H0: $\mathrm{p}=0$ [The correlation between the MSAF Employee's Intrinsic and General Job Satisfaction is equal to zero, in the employee population.]

H3: $p \neq 0$ [The correlation between the MSAF Employee's Intrinsic and General Job Satisfaction is not equal to zero, in the employee population.]

Hypothesis 4: There is no significant correlation between MSAF Employee's Extrinsic Satisfaction and General Job Satisfaction.

H0: $\mathrm{p}=0$ [The correlation between the MSAF Employee's Extrinsic and General Job Satisfaction is equal to zero, in the employee population.]

H4: $p \neq 0$ [The correlation between the MSAF Employee's Extrinsic and General Job Satisfaction is not equal to zero, in the employee population.

\section{Methodology}

During the months of December 2012 and January/February 2013, a structured survey questionnaire was personally administered in hard copy to all 66 MSAF employees, deployed in 11 locations across Fiji. They were ethnically diverse mariners and non-mariners who predominantly ranged in age between 21 and 60 years. We utilized a modified version of the Minnesota Satisfaction Questionnaire (MSQ) Long Form (Weiss et al., 1967) [24] as it is cognitive in its measure of job satisfaction (Smith et al., 1969) [47]. Cognitive measures are less temporary than affective measures, hence it was deemed, for the purposes of this study the MSQ was more appropriate (Moorman, 1993) [51].

The MSQ consists of 100 questions (that are designed to measure employee satisfaction), and 20 dimensions of the work environment that correspond to 20 psychological needs. The 20 dimensions of the MSQ are comprised of five questions, and are rated according to a 5-point Likert scale (Green, 2000) [52].

Further justification for using the MSQ Long Form was based on the instrument being popular among researchers (Spector, 1997) [26]; well developed (Buros, 1978) [53]; over time having shown to be a well known and a stable instrument (Martins and Proenca, 2012) [45]; and previous research yielded excellent coefficient alpha values (ranging from 0.85 to 0.91) (Martins and Proenca, 2012) [45]. Moreover, the MSQ has been widely studied and validated (Fields, 2002) [54]; and, its intrinsic and extrinsic subsections have consistently demonstrated 
acceptable internal consistency with different samples (Cook et al., 1981) [55].

Twenty questions of the MSQ Long Form constitute the MSQ Short Form, and are used to measure three scales-intrinsic, extrinsic and general satisfaction. MSQ scores obtained from this research were interpreted against percentile scores for the most appropriate normative group (Weiss et al., 1967) [24]. For the purposes of this study the normative data for engineers was deemed most suitable and utilized (Weiss et al., 1967) [24].

Frequency mean scores, standard deviations, and percentile scores, referenced to normative data percentiles for the reference group (Weiss et al., 1967) [24] were determined for the 20 dimensions of the modified MSQ Long Form, and resultant degree of employee satisfaction by dimension; and for the intrinsic, extrinsic and general employee satisfaction, and resultant degree of employee satisfaction for MSAF employees. A One Sample t-Test was undertaken to assess whether the means of two groups (MSAF employees and the normative reference group) were statistically different from each other. Pearson product-moment correlation coefficients were calculated to enable the researcher to measure the strength of association between MSAF employees' intrinsic, extrinsic and general job satisfaction.

\section{Results}

The paper-based survey response rate achieved was 95\%. In Table 1 we array the results of the Cronbach's Alpha Coefficient for Internal Efficiency for this modified MSQ Long Form instrument (0.984) and for the sub-scales: intrinsic (0.790), extrinsic (0.828) and general (0.805).

In terms of the 20 dimensions of the MSQ, Table 2 reveals a wide variation in MSQ dimensions of employee

Table 1. Cronbach alpha values for this modified MSQ instrument.

\begin{tabular}{cc}
\hline MSQ Instrument & Cronbach's Alpha Values \\
\hline Intrinsic Sub-scale & 0.790 \\
Extrinsic Sub-scale & 0.828 \\
General Sub-scale & 0.805 \\
MSQ Overall Questionnaire & 0.984 \\
\hline
\end{tabular}

Table 2. Summary of total mean scores, standard deviations, percentile scores and degree of satisfaction by MSQ dimension.

\begin{tabular}{|c|c|c|c|c|}
\hline Dimensions & Mean & Standard Deviation & Percentile & Degree of Satisfaction \\
\hline Ability Utilization & 18.37 & 4.70 & $30-40$ & Average \\
\hline Achievement & 18.01 & 4.92 & $20-30$ & Low \\
\hline Activity & 18.38 & 4.79 & $10-20$ & Low \\
\hline Advancement & 15.63 & 4.94 & $35-40$ & Average \\
\hline Authority & 17.65 & 4.69 & $20-30$ & Average \\
\hline Policies and Procedure & 14.36 & 5.88 & $15-20$ & Low \\
\hline Compensation & 13.33 & 5.62 & $20-25$ & Low \\
\hline Co-Workers & 18.29 & 4.91 & $10-25$ & Low \\
\hline Creativity & 17.36 & 5.03 & $15-20$ & Low \\
\hline Independence & 18.00 & 4.99 & $20-25$ & Low \\
\hline Moral Values & 17.82 & 5.52 & 1 & Low \\
\hline Recognition & 16.61 & 5.21 & $25-30$ & Average \\
\hline Responsibility & 17.79 & 4.92 & $10-15$ & Low \\
\hline Security & 15.87 & 5.68 & $1-5$ & Low \\
\hline Social Service & 18.78 & 4.92 & $15-20$ & Low \\
\hline Social Status & 16.78 & 4.87 & $25-30$ & Average \\
\hline Supervision-Human-Relations & 16.34 & 5.78 & $15-25$ & Low \\
\hline Supervision-Technical & 16.82 & 5.26 & $25-30$ & Average \\
\hline Variety & 17.65 & 4.99 & $10-15$ & Low \\
\hline Working Conditions & 14.71 & 5.96 & $15-20$ & Low \\
\hline
\end{tabular}


satisfaction means, ranging from compensation $(M=13.33, S D=5.62)$ to social service $(M=18.78, S D=4.92)$; percentile scores ranging from moral values (1\%) to ability utilization (30\% - 40\%); and degree of job satisfaction (low-average). MSAF employees scored 14 (70\%) of the MSQ dimensions of employee satisfaction as a low degree of employee satisfaction, and $6(30 \%)$ an average degree of employee satisfaction.

In Table 3 we array the frequency distribution, normative degree of intrinsic job satisfaction, and associated percentage scores of the intrinsic scale. The analysis reveals the mean score for the intrinsic satisfaction scale ( $M=38.37, S D=8.10)$. Using the normative data for the reference group the mean score fell between the $5^{\text {th }}$ and $10^{\text {th }}$ percentile. Further analysis revealed, that of the MSAF employees who participated in this study, 50 (79.37\%) reported low levels of intrinsic satisfaction; 12 (19.05\%) reported an average level of intrinsic satisfaction; and, 1 (1.59\%) reported high levels of intrinsic satisfaction.

In Table 4 we array the frequency distribution, normative degree of extrinsic job satisfaction, and associated

Table 3. Frequency distribution of the intrinsic job satisfaction scale.

\begin{tabular}{|c|c|c|c|c|c|c|c|}
\hline & & Frequency & $\begin{array}{l}\text { Valid } \\
\text { Percent }\end{array}$ & $\begin{array}{l}\text { Cumulative } \\
\text { Percent }\end{array}$ & $\begin{array}{c}\text { Degree of } \\
\text { Intrinsic Job }\end{array}$ & $\begin{array}{l}\text { Total } \\
\text { Frequency }\end{array}$ & $\begin{array}{l}\text { Percentage Low/Average/High } \\
\text { Intrinsic Job Satisfaction }\end{array}$ \\
\hline & 20 & 1 & 1.60 & 1.60 & Low & & \\
\hline & 22 & 1 & 1.60 & 3.20 & Low & & \\
\hline & 23 & 2 & 3.20 & 6.30 & Low & & \\
\hline & 25 & 1 & 1.60 & 7.90 & Low & & \\
\hline & 27 & 1 & 1.60 & 9.50 & Low & & \\
\hline & 28 & 1 & 1.60 & 11.10 & Low & & \\
\hline & 30 & 4 & 6.30 & 17.50 & Low & & \\
\hline & 31 & 2 & 3.20 & 20.60 & Low & & \\
\hline & 32 & 1 & 1.60 & 22.20 & Low & & \\
\hline & 33 & 5 & 7.90 & 30.20 & Low & & \\
\hline & 34 & 3 & 4.80 & 34.90 & Low & & \\
\hline & 35 & 1 & 1.60 & 36.50 & Low & & \\
\hline & 36 & 3 & 4.80 & 41.30 & Low & & \\
\hline & 37 & 3 & 4.80 & 460 & Low & & \\
\hline Valid & 38 & 1 & 1.60 & 47.60 & Low & & \\
\hline & 39 & 3 & 4.80 & 52.40 & Low & & \\
\hline & 40 & 1 & 1.60 & 54.00 & Low & & \\
\hline & 41 & 2 & 3.20 & 57.10 & Low & & \\
\hline & 42 & 6 & 9.50 & 66.70 & Low & & \\
\hline & 43 & 3 & 4.80 & 71.40 & Low & & \\
\hline & 44 & 5 & 7.90 & 79.40 & Low & 50 & 79.36 \\
\hline & 45 & 3 & 4.80 & 84.10 & Average & & \\
\hline & 47 & 1 & 1.60 & 85.70 & Average & & \\
\hline & 48 & 2 & 3.20 & 88.90 & Average & & \\
\hline & 49 & 3 & 4.80 & 93.70 & Average & & \\
\hline & 50 & 1 & 1.60 & 95.20 & Average & & \\
\hline & 51 & 1 & 1.60 & 96.80 & Average & & \\
\hline & 53 & 1 & 1.60 & 98.40 & Average & 12 & 19.05 \\
\hline & 55 & 1 & 1.60 & 100.00 & High & 1 & 1.59 \\
\hline & Total & 63 & 100.00 & & & 63 & 100.00 \\
\hline
\end{tabular}

Note. Mean: 38.37; Median: 39.00; Mode: 42.00; Standard Deviation: 8.10; Minimum: 20.00; Maximum: 55.00; Range: 35. 
Table 4. Frequency distribution of the extrinsic job satisfaction scale.

\begin{tabular}{|c|c|c|c|c|c|c|c|}
\hline & & Frequency & $\begin{array}{c}\text { Valid } \\
\text { Percent }\end{array}$ & $\begin{array}{c}\text { Cumulative } \\
\text { Percent }\end{array}$ & $\begin{array}{c}\text { Degree of } \\
\text { Extrinsic Job } \\
\text { Satisfaction }\end{array}$ & $\begin{array}{c}\text { Total } \\
\text { Frequency } \\
\text { Count }\end{array}$ & $\begin{array}{l}\text { Percentage Low/Average/High } \\
\text { Extrinsic Job Satisfaction }\end{array}$ \\
\hline \multirow{20}{*}{ Valid } & 10 & 1 & 1.60 & 1.60 & Low & & \\
\hline & 11 & 1 & 1.60 & 3.20 & Low & & \\
\hline & 12 & 1 & 1.60 & 4.80 & Low & & \\
\hline & 14 & 1 & 1.60 & 6.30 & Low & & \\
\hline & 15 & 4 & 6.30 & 12.70 & Low & & \\
\hline & 16 & 2 & 3.20 & 15.90 & Low & & \\
\hline & 17 & 2 & 3.20 & 19.00 & Low & 12 & 19.05 \\
\hline & 18 & 1 & 1.60 & 20.60 & Average & & \\
\hline & 19 & 2 & 3.20 & 23.80 & Average & & \\
\hline & 20 & 7 & 11.1 & 34.90 & Average & & \\
\hline & 21 & 6 & 9.50 & 44.40 & Average & & \\
\hline & 22 & 8 & 12.7 & 57.10 & Average & & \\
\hline & 23 & 6 & 9.50 & 66.70 & Average & & \\
\hline & 24 & 8 & 12.7 & 79.40 & Average & 38 & 60.32 \\
\hline & 25 & 4 & 6.30 & 85.70 & High & & \\
\hline & 26 & 3 & 4.80 & 90.50 & High & & \\
\hline & 27 & 2 & 3.20 & 93.70 & High & & \\
\hline & 28 & 2 & 3.20 & 96.80 & High & & \\
\hline & 29 & 2 & 3.20 & 100.00 & High & 13 & 20.63 \\
\hline & Total & 63 & 100.00 & & & 63 & 100.00 \\
\hline
\end{tabular}

Note. Mean: 21.38; Median: 22.00; Mode: 22.00; Standard Deviation: 4.27; Minimum: 10.00; Maximum: 29.00 ; Range: 19.

percentage scores of the extrinsic scale. The analysis reveals the mean score for the extrinsic satisfaction scale $(M=21.38, S D=4.27)$. Using the normative data for the reference group the mean score fell between the $45^{\text {th }}$ and $55^{\text {th }}$ percentile. Further analysis revealed that of the MSAF employees, who participated in this study, 12 (19.05\%) reported low levels of extrinsic satisfaction; 38 (60.32\%) reported an average level of extrinsic satisfaction; and, 13 (20.63\%) reported high levels of extrinsic satisfaction.

In Table 5 we array the frequency distribution, normative degree of intrinsic job satisfaction, and associated percentage scores of the general scale. The analysis reveals that the mean score for the general satisfaction scale ( $M=63.63, S D=12.08)$. Using the normative data for the reference group the mean score fell between the $5^{\text {th }}$ and $10^{\text {th }}$ percentile. Further analysis revealed that of the MSAF employees, who participated in this study, 44 (69.84\%) reported low levels of general satisfaction; 7 (11.11\%) reported an average level of general satisfaction; and, $12(19.05 \%)$ reported high levels of general satisfaction.

Table 6 descriptive statistics reveal that the MSAF total general satisfaction score $(M=63.63, S D=12.08)$ was lower than the general satisfaction mean for the reference group score of 77.88.

Table 7 reveals that the MSAF total general satisfaction score was statistically significantly lower than the general satisfaction mean for the reference group score, $t(62)=-9.361, p=0.000$. In addition, the MSAF total general satisfaction score was statistically significantly lower by a mean of 14.25, 95\% CI [11.20 to 17.29], than the general satisfaction mean for the reference group score of 77.88, $t(62)=-9.361, p=0.000$. There was a statistically significant difference between the means $(p<0.05)$ and, therefore, we can reject the null hypothesis and accept the alternative hypothesis (H1).

In Table 8 we array the Pearson product-moment correlation coefficients between the MSAF employee's Intrinsic, Extrinsic, and General Job satisfaction. A Pearson product-moment correlation coefficient was computed to assess the relationship between MSAF Employee's Intrinsic and Extrinsic Job Satisfaction. There was a positive correlation between the two variables, $\mathrm{r}=0.735, \mathrm{n}=63, p=0.000$. Overall, there was a strong, positive 
Table 5. Frequency distribution of the general job satisfaction scale.

\begin{tabular}{|c|c|c|c|c|c|c|c|}
\hline & & Frequency & $\begin{array}{l}\text { Valid } \\
\text { Percent }\end{array}$ & $\begin{array}{l}\text { Cumulative } \\
\text { Percent }\end{array}$ & $\begin{array}{l}\text { Degree of } \\
\text { General Job } \\
\text { Satisfaction }\end{array}$ & $\begin{array}{l}\text { Total } \\
\text { Frequency } \\
\text { Count }\end{array}$ & $\begin{array}{l}\text { Percentage Low/Average/High } \\
\text { General Job Satisfaction }\end{array}$ \\
\hline & 30 & 1 & 1.60 & 1.60 & Low & & \\
\hline & 36 & 1 & 1.60 & 3.20 & Low & & \\
\hline & 37 & 1 & 1.60 & 4.80 & Low & & \\
\hline & 41 & 1 & 1.60 & 6.30 & Low & & \\
\hline & 44 & 1 & 1.60 & 7.90 & Low & & \\
\hline & 46 & 2 & 3.20 & 11.10 & Low & & \\
\hline & 50 & 1 & 1.60 & 12.70 & Low & & \\
\hline & 51 & 1 & 1.60 & 14.30 & Low & & \\
\hline & 52 & 1 & 1.60 & 15.90 & Low & & \\
\hline & 53 & 1 & 1.60 & 17.50 & Low & & \\
\hline & 54 & 2 & 3.20 & 20.60 & Low & & \\
\hline & 55 & 1 & 1.60 & 22.20 & Low & & \\
\hline & 56 & 3 & 4.80 & 27.00 & Low & & \\
\hline & 57 & 1 & 1.60 & 28.60 & Low & & \\
\hline & 58 & 2 & 3.20 & 31.70 & Low & & \\
\hline & 59 & 3 & 4.80 & 36.50 & Low & & \\
\hline & 61 & 1 & 1.60 & 38.10 & Low & & \\
\hline Valid & 62 & 1 & 1.60 & 39.70 & Low & & \\
\hline & 63 & 2 & 3.20 & 42.90 & Low & & \\
\hline & 64 & 2 & 3.20 & 46.00 & Low & & \\
\hline & 65 & 1 & 1.60 & 47.60 & Low & & \\
\hline & 67 & 5 & 7.90 & 55.60 & Low & & \\
\hline & 68 & 2 & 3.20 & 58.70 & Low & & \\
\hline & 69 & 4 & 6.30 & 65.10 & Low & & \\
\hline & 70 & 3 & 4.80 & 69.80 & Low & 44 & 69.84 \\
\hline & 71 & 3 & 4.80 & 74.60 & Average & & \\
\hline & 72 & 4 & 6.30 & 81.00 & Average & 7 & 11.11 \\
\hline & 73 & 3 & 4.80 & 85.70 & High & & \\
\hline & 75 & 1 & 1.60 & 87.30 & High & & \\
\hline & 77 & 1 & 1.60 & 88.90 & High & & \\
\hline & 78 & 1 & 1.60 & 90.50 & High & & \\
\hline & 80 & 3 & 4.80 & 95.20 & High & & \\
\hline & 81 & 2 & 3.20 & 98.40 & High & & \\
\hline & 91 & 1 & 1.60 & 100.00 & High & 12 & 19.05 \\
\hline & Total & 63 & 100.00 & & & 63 & 100.00 \\
\hline
\end{tabular}

Note. Mean: 63.63; Median: 67.00; Mode: 67.00; Standard Deviation: 12.08; Minimum: 30.00; Maximum: 91.00 ; Range: 61.

correlation between MSAF Employee's Intrinsic and Extrinsic Job Satisfaction, and we can reject the null hypothesis and accept the alternative hypothesis (H2).

A Pearson product-moment correlation coefficient was computed to assess the relationship between MSAF Employee's Intrinsic and General Job Satisfaction. There was a positive correlation between the two variables, $r=$ 0.952, $\mathrm{n}=63, p=0.000$. Overall, there was a strong, positive correlation between MSAF Employee's Intrinsic 
Table 6. One-sample statistics.

\begin{tabular}{ccccc}
\hline & N & Mean & Std. Deviation & Std. Error Mean \\
\hline Total General & 63 & 63.63 & 12.08 & 1.52 \\
\hline
\end{tabular}

Table 7. One-sample t-test.

\begin{tabular}{|c|c|c|c|c|c|c|}
\hline & \multicolumn{6}{|c|}{ Test Value $=77.88$} \\
\hline & \multirow{2}{*}{$\mathbf{t}$} & \multirow{2}{*}{ df } & \multirow{2}{*}{ Sig. (2-tailed) } & \multirow{2}{*}{ Mean Difference } & \multicolumn{2}{|c|}{ 95\% Confidence Interval of the Difference } \\
\hline & & & & & Lower & Upper \\
\hline Total General & -9.361 & 62 & 0.000 & -14.2451 & -17.2869 & -11.2032 \\
\hline
\end{tabular}

Table 8. Pearson product-moment correlation between the MSAF employee's intrinsic, extrinsic, and general job satisfaction.

\begin{tabular}{|c|c|c|c|c|}
\hline & & Total Intrinsic & Total Extrinsic & Total General \\
\hline \multirow{3}{*}{ Total Intrinsic } & Pearson Correlation & 1 & & \\
\hline & Sig. (2-tailed) & & & \\
\hline & $\mathrm{N}$ & & & \\
\hline \multirow{3}{*}{ Total Extrinsic } & Pearson Correlation & $0.735^{* *}$ & 1 & \\
\hline & Sig. (2-tailed) & $0.000^{*}$ & & \\
\hline & $\mathrm{N}$ & 63 & & \\
\hline \multirow{3}{*}{ Total General } & Pearson Correlation & $0.952^{* *}$ & $0.892^{* *}$ & 1 \\
\hline & Sig. (2-tailed) & $0.000^{*}$ & $0.000^{*}$ & \\
\hline & $\mathrm{N}$ & 63 & 63 & \\
\hline
\end{tabular}

Note. “**” Correlation is significant at the 0.01 level (2-tailed). “*” Correlation is significant at the 0.05 level (2-tailed).

and General Job Satisfaction, and we can reject the null hypothesis and accept the alternative hypothesis (H3).

A Pearson product-moment correlation coefficient was computed to assess the relationship between MSAF Employee's Extrinsic and General Job Satisfaction. There was a positive correlation between the two variables, $r=0.892, n=63, p=0.000$. Overall, there was a strong, positive correlation between MSAF Employee's Extrinsic and General Job Satisfaction, and we can reject the null hypothesis and accept the alternative hypothesis (H4).

\section{Discussion}

This article examined the job satisfaction level of the employees of the Maritime Safety Authority of Fiji (MSAF), through the use of a modified Minnesota Satisfaction Questionnaire (MSQ) Long Form instrument. Based on the Cronbach's alpha values calculated for this modified MSQ Long Form instrument and the subscales, the instrument was considered reliable/probably reliable, with a high degree of internal consistency, thereby adding validity and accuracy to the interpretation of this research's data.

The dominant finding of this research study in Fiji highlights that MSAF employees are not satisfied with the reform mainly due to the politics-administration dichotomy, and series of other factors, compounded by contradictory and competing views, opinions, and interests regarding the reform. This has led to degradation of job satisfaction and increased resistance to reform. The findings of this study reveal that in terms of the MSQ dimensions of employee satisfaction, a wide variation in responses existed, and a low degree of employee satisfaction predominated. The results identified a low level of intrinsic satisfaction, average level of extrinsic satisfaction, and a low level of general satisfaction for the employees. This study also reveals that strong/large, significant, positive correlations existed between MSAF employee's intrinsic, extrinsic and general job satisfaction but there is no significant correlation between MSAF Employee's Extrinsic Satisfaction and General Job Satisfaction.

\section{Conclusion, Limitations and Directions for the Future Research}

The findings reported here are evidence that Fiji’s Public Sector reforms in general and MSAF in particular have 
not contributed to improving the job satisfaction. On the basis of general feedback from employees, research findings and observations confirmed a general lack of job satisfaction by employees. Employees expressed concerns about the level of accountability; pay reform did not lead to expected salary increase; insufficient empowerment; insufficient autonomy from the government; lack of clarity of goals; and contradictory and competing views and opinions regarding goals and priorities had led to disjointed, demotivated and uncommitted employees. This study supports the conception that bureaucratic attributes of public service entities in combination with other factors constrains job satisfaction among public service employees. Study makes its theoretical contribution primarily to the literature on the assessment of public service job satisfaction, and to the scarce theoretical strands relating to public service safety organisations.

This paper forms an integral part of a larger research-Change management challenges in the reform of the Maritime Safety Authority of Fiji (MSAF). The main outcome of this research is its contribution towards a policy paper that can be a vital resource for government policy planners, and MSAF board and management, for ongoing reform of MSAF and the maritime industry of Fiji. While history has shown that many public sector reform efforts have failed to achieve the desired outcomes, this research has provided a platform from which sound and well-researched public sector reform "adjustments" and plans could be made, and acted upon with confidence. This would not only increase the likelihood of successful reform efforts without much resistance but at the same time also increase employee satisfaction.

This study has several limitations. First, the sample size is small due to one public sector undertaking that was part of this research. Second limitation of this study relates to the fact that our findings are not generalizable, and the small country (and small public sector undertaking) focus meant that we had to be curious in protecting the confidentiality of our participants. Lastly, we recognize that our research study covers a limited number of quantitative and qualitative indicators of employee job satisfaction that were more relevant to Fiji situation in general and MSAF in particular.

Our findings suggest several avenues for future investigations. First, more research is needed to clarify how the variables included in our study relate to employee feelings of work engagement and satisfaction. Second, considering the ongoing reform of MSAF, and that it is preferred to utilize the MSQ instrument on a recurrent basis, future research should be carried out to periodically measure and analyze MSAF employee job satisfaction development. Lastly, future research should also examine the variables that are causes of, and explain, job satisfaction and dissatisfaction; examine the relationship between job satisfaction and the independent variables (demographics) of MSAF employees; and, in order to enhance the understanding of the concept of public service employee job satisfaction and how it is measured; because this is paramount for public service providers such as MSAF, in terms of employee "health”, and organisational performance, profitability and growth.

\section{References}

[1] Bajpai, N. and Srivastava, D. (2004) Sectorial Comparison of Factors Influencing Job Satisfaction in Indian Banking Sector. Singapore Management Review, 26, 89-99.

[2] Ellickson, M.C. (2002) Determinants of Job Satisfaction of Municipal Government Employees. Public Personnel Management, 31, 343-359. http://dx.doi.org/10.1177/009102600203100307

[3] Pollock, T., Whitbred, R. and Contractor, N. (2000) Social Information Processing and Job Characteristics: A Simultaneous Test of Two Theories with Implications for Job Satisfaction. Human Communication Research, 26, $292-330$. http://dx.doi.org/10.1111/j.1468-2958.2000.tb00759.x

[4] Kroll, P.I.A. (2011) What Makes E-Government a Satisfying Place for Employment? An Internal Perspective on Service. Doctoral Thesis, University of Twente, Enschede. http://essay.utwente.nl/61290/1/Kroll_Pia_-s_1027158_scriptie.pdf

[5] Ibarra, H. and Andrews, S. (1993) Power, Social Influence, and Sense Making: Effects of Network Centrality and Proximity on Employee Perceptions. Administrative Science Quarterly, 38, 277-303. http://dx.doi.org/10.2307/2393414

[6] Ting, Y. (1997) Determinants of Job Satisfaction of Federal Government Employees. Public Personnel Management, 26, 313-328. http://dx.doi.org/10.1177/009102609702600302

[7] Wright, E.B. (2001) Public-Sector Work Motivation: A Review of the Current Literature and a Revised Conceptual Model. Journal of Public Administration Research and Theory, 11, 559-586. http://dx.doi.org/10.1093/oxfordjournals.jpart.a003515 
[8] Baldwin, J.N. and Farley, Q.A. (1991) Comparing the Public and Private Sectors in the United States: A Review of the Empirical Literature. In: Farazmand, A., Ed., Handbook of Comparative and Development Public Administration, Marcel Delcker, New York.

[9] Fottler, M.D. (1981) Is Management Really Generic? Academy of Management Review, 6, 1-12. http://dx.doi.org/10.5465/AMR.1981.4287972

[10] Rainey, H.G. (1989) Public Management: Recent Research on the Political Context and Managerial Roles, Structures and Behaviors. Journal of Management, 15, 229-250. http://dx.doi.org/10.1177/014920638901500206

[11] Whorton, J.W. and Worthley, J.A. (1981) A Perspective on the Challenge of Public Management: Environmental Paradox and Organizational Culture. Academy of Management Review, 6, 357-361.

[12] Steel, B.S. and Warner, R.L. (1990) Job Satisfaction among Early Labor Force Participants: Unexpected Outcomes in Public and Private Sector Comparisons. Review of Public Personnel Administration, 10, 4-22. http://dx.doi.org/10.1177/0734371X9001000302

[13] Baldwin, I.N. (1984) Are We Really Lazy? Review of Public Personnel Administration, 4, 80-89.

[14] Blank, R.M. (1985) An Analysis of Workers' Choice between Employment in the Public and Private Sectors. Industrial and Labor Relations Review, 38, 211-224. http://dx.doi.org/10.1177/001979398503800204

[15] Fogel, W. and Lewin, D. (1974) Wage Determination in the Public Sector. Industrial and Labor Relations Review, 27, 411-422. http://dx.doi.org/10.1177/001979397402700306

[16] Paine, F.T., Carroll, S.J. and Leete, B.A. (1966) Need Satisfactions of Managerial Level Personnel in a Government Agency. Journal of Applied Psychology, 50, 247-249. http://dx.doi.org/10.1037/h0023422

[17] Porter, L.W. and Mitchell, V.F. (1967) Comparative Study of Need Satisfactions in Military and Business Hierarchies. Journal of Applied Psychology, 51, 139-144. http://dx.doi.org/10.1037/h0024467

[18] Rhinehart, J.B., Barrell, R.P., DeWolfe, A.S., Griffin, J.E. and Spaner, F.E. (1969) Comparative Study of Need Satisfactions in Governmental and Business Hierarchies. Journal of Applied Psychology, 53, 230-235. http://dx.doi.org/10.1037/h0027413

[19] Solomon, E.E. (1986) Private and Public Sector Managers: An Empirical Investigation of Job Characteristics and Organizational Climate. Journal of Applied Psychology, 71, 247-259. http://dx.doi.org/10.1037/0021-9010.71.2.247

[20] Newstrom, J.W., Reif, W.E. and Monczka, R.M. (1976) Motivating the Public Employee: Fact vs. Fiction. Public Personnel Management, 5, 67-72. http://dx.doi.org/10.1177/009102607600500108

[21] Edvardsen, B., Tomasson, B. and Ovretveit, J. (1994) Quality of Service: Making It Really Work. McGraw-Hill, New York.

[22] Velnampy, T. and Sivesan, P. (2012) Determinants of Employees' Job Satisfaction: A Study of Banking Industries in Sri Lanka. Global Journal of Management and Business Research, 12, 22-29.

[23] Kumari, G., Joshi, G. and Pandey, K.M. (2015) Factors Influencing of Job Satisfaction among Employees in Software Industries: A Case Study of Wipro Ltd., Greater Noida, India. Advances in Economics and Business Management $(A E B M), 2,751-755$.

[24] Weiss, D.J., Davis, R.V., England, G.W. and Lofquist, L.H. (1967) Manual for the Minnesota Satisfaction Questionnaire. The University of Minnesota Press, Minneapolis.

[25] Miarkolaei, H.S. and Miarkolaei, H.S. (2014) An Investigation of Relationship between Employees’ Biographical Characteristics, Job Satisfaction and Organizational Commitment. Journal of Applied Science and Agriculture, 9, 578590.

[26] Spector, P.E. (1997) Job Satisfaction: Application, Assessment, Cause, and Consequences. Sage, London.

[27] Agho, A.O., Mueller, C.W. and Price, J.L. (1993) Determinants of Employee Job Satisfaction: An Empirical Test of a Causal Model. Human Relations, 46, 1007-1027. http://dx.doi.org/10.1177/001872679304600806

[28] Price, J.L. and Mueller, C.W. (1986) Absenteeism and Turnover among Hospital Employees. JAI Press, Greenwich.

[29] Knoop, R. (2001) Relieving Stress through Value-Rich Work. Journal of Social Psychology, 134, 829-836. http://dx.doi.org/10.1080/00224545.1994.9923017

[30] McCormick, E.J. and Ilgen, D. (1985) Industrial and Organizational Psychology. 8th Edition, Allen and Unwin, London.

[31] Wanous, J.P. and Lawler, E.E. (1972) Measurement and Meaning of Job Satisfaction. Journal of Applied Psychology, 56, 95-105. http://dx.doi.org/10.1037/h0032664

[32] Herzberg, F., Mausner, B. and Snyderman, B. (1959) The Motivation to Work. 2nd Edition, John Wiley \& Sons, New York. 
[33] Maslow, A.H. (1954) Motivation and Personality. Harper \& Brothers Publishers, New York.

[34] Dartey-Baah, K. and Amoako, G.K. (2011) Application of Frederick Herzberg’s Two-Factor Theory in Assessing and Understanding Employee Motivation at Work: A Ghanaian Perspective. European Journal of Business and Management, 3, 1-8.

[35] Prothero, M.M., Marshall, E.S. and Fosbinder, D.M. (1999) Implementing Differentiated Practice: Personal Values and Work Satisfaction among Hospital Staff Nurses. Journal for Nurses in Staff Development, 15, 185-192. http://dx.doi.org/10.1097/00124645-199909000-00002

[36] Nachimuthu, P. (2006) A Study of Job Satisfaction among Male and Female Police Personnel. The Indian Police Journal, LIII, 93-101.

[37] Michael, D.R. and Jihong, Z. (1999) The Determinants of Job Satisfaction among United States Air Force Security Police. Review of Public Personnel Administration, 19, 5-19. http://dx.doi.org/10.1177/0734371X9901900301

[38] Brunetto, Y. and Farr-Wharton, R. (2002) Using Social Identity Theory to Explain the Job Satisfaction of Public Sector Employees. The International Journal of Public Sector Management, 15, 534-551. http://dx.doi.org/10.1108/09513550210448571

[39] Card, D., Mas, A., Moretti, E. and Saez, E. (2012) Inequality at Work: The Effect of Peer Salaries on Job Satisfaction. The American Economic Review, 102, 2981-3003. http://dx.doi.org/10.1257/aer.102.6.2981

[40] Luthmer, E. (2005) Neighbors as Negatives: Relative Earnings and Well-Being. Quarterly Journal of Economics, 120, 963-1002.

[41] Wenshu, G.A.O. and Smyth, R. (2010) Job Satisfaction and Relative Income in Economic Transition: Status or Signal? The Case of Urban China. China Economic Review, 21, 442-455. http://dx.doi.org/10.1016/j.chieco.2010.04.002

[42] Clark, A.E., Kristensen, N. and Westergard-Nielsen, N. (2009) Job Satisfaction and Co-Worker Wages: Status or Signal? Economic Journal, 119, 430-447. http://dx.doi.org/10.1111/j.1468-0297.2008.02236.X

[43] Weathington, B.L. and Reddock, C.M. (2011) Equity Sensitivity in "Fringe" Benefit Value and Satisfaction. Journal of Behavioral and Applied Management, 13, 44-59.

[44] Judge, T.A., Piccolo, R.F., Podsakoff, N.P., Shaw, J.C. and Rich, B.L. (2010) The Relationship between Pay and Job Satisfaction: A Meta-Analysis of the Literature. Journal of Vocational Behavior, 77, 157-167. http://dx.doi.org/10.1016/j.jvb.2010.04.002

[45] Martins, H. and Proença, T. (2012) Minnesota Satisfaction Questionnaire-Psychometric Properties and Validation in a Population of Portuguese Hospital Workers. FEP Working Papers, retrieved from University of Porto website. http://wps.fep.up.pt/wps/wp471.pdf

[46] Spagnoli, P., Caetano, A. and Santos, S.C. (2012) Satisfaction with Job Aspects: Do Patterns Change over Time? Journal of Business Research, 65, 609-616. http://dx.doi.org/10.1016/j.jbusres.2011.02.048

[47] Wanous, J.P., Reichers, A.E. and Hudy, M.J. (1997) Overall Job Satisfaction: How Good Are Single-Item Measures? Journal of Applied Psychology, 82, 247-252. http://dx.doi.org/10.1037/0021-9010.82.2.247

[48] Smith, P.C., Kendall, L.M. and Hulin, C.L. (1969) The Measurement of Satisfaction in Work and Retirement. Rand McNally, Chicago.

[49] Spector, P.E. (1985) Measurement of Human Service Staff Satisfaction: Development of the Job Satisfaction Survey. American Journal of Community Psychology, 13, 693-713. http://dx.doi.org/10.1007/BF00929796

[50] Gregory, J.B. and Levy, P.E. (2011) It’s Not Me, It’s You: A Multilevel Examination of Variables That Impact Employee Coaching Relationships. Consulting Psychology Journal: Practice and Research, 63, 67-88. http://dx.doi.org/10.1037/a0024152

[51] Moorman, R.H. (1993) The Influence of Cognitive and Affective Based Job Satisfaction Measures on the Relationship between Satisfaction and Organizational Citizenship Behavior. Human Relations, 46, 759-776. http://dx.doi.org/10.1177/001872679304600604

[52] Green, J. (2000) Job Satisfaction of Community College Chairpersons. Doctoral Thesis, Virginia Polytechnic Institute and State University, Blacksburg. http://citeseerx.ist.psu.edu/viewdoc/download?doi=10.1.1.5.1160\&rep=rep1\&type=pdf

[53] Buros, O.K. (1978) The Eighth Mental Measurements Yearbook. 2nd Edition, Gryphon Press, New Jersey.

[54] Fields, D.L. (2002) Taking the Measure of Work: A Guide to Validated Scales for Organizational Research and Diagnosis. Sage, Thousand Oaks.

[55] Cook, J.D., Hepworth, S.J., Wall, T.D. and Warr, P.B. (1981) The Experience of Work. Academic Press, London. 